\title{
Dollars are green too
}

\section{Washington}

US administration officials promised last week that they would unveil "concrete proposals", including an international global change research programme, at the first White House international conference on global climate change, which is being held in Washington this week. The meeting, to be opened with a major environmental policy address by President Bush, has been presented as an opportunity to address the economic issues that the administration believes have been overlooked in global climate change negotiations.

But foreign participants complained that the agenda of the meeting seemed oriented towards further research instead of action, emphasized the economic costs of countermeasures and repeated many of the issues already being discussed within the United Nations, which is the designated central organizing body for global climate change policy making. And in a week that ends with Earth Day, environmentalists converged on the meeting to lobby for tough cuts in greenhouse gas emissions, rather than "stalling" with more research.

White House science adviser D. Allen Bromley last week outlined a proposal for collaborative research initiative "comparable on the international scene to the US national programme". The collaboration could include a joint-funding pool for global change research, coordination of existing research programmes, and backing for Third World projects, such as Indonesia's proposal to build a giant radar to explore the little-understood equatorial atmosphere.

The conference, which fulfils a promise from George Bush's 1988 presidential campaign, was first announced at the Malta summit last December. Since then, US planners have rushed to try to assemble an agenda that will not duplicate the policy-making process of the UN Intergovernmental Panel on Climate Change (IPCC).

But as ministers from 17 nations, the European Community, and the Organization for Economic Cooperation and Development gathered in Washington, diplomats from the invited countries said they were puzzled by the preliminary agenda, which promised discussion on issues such as "how well can we predict temperature trends?" and "how 'good' are our global [climate] models?" Questions of that sort are already the purview of the IPCC, where a panel chaired by Britain is preparing to release its own scientific analysis in May (Nature 344, 577; 12 April 1990). Environmentalists suggest that the meeting is an attempt to get a "second opinion" in anticipation of ominous con- clusions from the IPCC. "In essence, the focus of the White House conference is akin to saying 'we don't like those projections", Alden Meyer of the Union of Concerned Scientists told Congress earlier this month.

White House officials hope that the conference will spur new economic research to determine the real costs of global warming response measures such as energy-efficiency standards and "carbon taxes". "We feel that the economic aspects have not been studied to the degree that they might", says Michael Deland, chairman of the White House Council on Environmental Quality.

While many economists believe that the strict controls on emissions of carbon dioxide now advocated by many European countries will cost more than they will save in energy efficiency, environmentalists claim that going green will save money. But hard numbers are in short supply.

Bush adminstration officials have been outspoken in their belief that a 20 per cent reduction of US carbon output by early in the next century would be extraordinarily expensive - costing as much as $\$ 3.6$ million million according to one estimate but they admit that there have been almost no reliable economic studies to back that up.

In part to ascertain the current state of knowledge on the economics of global warming, the White House asked the 18 visiting delegations to fill out a 23question survey on the scope, details, and conclusions of their economic and scientific research on climate change. But several countries have reacted badly to the questionnaire, saying that the questions appeared to be slanted towards the high economic cost of dealing with global warming.

At least one nation - West Germany - refused to answer the questionnaire, objecting to "leading questions" that implied a choice between research and response measures. A West German position paper submitted in the survey's place stresses the need for immediate action.

Besides questions about the amount, types and mechanisms of global warming research in the invited countries, the US survey asked the delegates to identify "possible conflicts, if any, between your interest in continued economic progress and your interest in arresting possible undesirable global change".

West German chancellor Helmut Kohl wrote to Bush earlier this month asking that the White House modify the conference's agenda to place greater emphasis on practical policy responses, rather than further research. But US officials say that policy moves at this point could preempt
US eases controversial visa restrictions

\section{Washington}

IN an attempt to quell mounting opposition to its restrictions on entry into the United States for people with AIDS, the Bush administration last week announced a new no-questions-asked, 10 -day visa for visitors attending certain US scientific and medical conferences.

Rather than stating that they are infected with the AIDS virus and answering a series of questions to determine the risk they present to the public, people with AIDS who are going to designated US conferences will be able to obtain a visa simply by giving the name of the conference and satisfying normal entry standards, the Immigration and Naturalization Service said. The first two conferences for which the special visas will apply are the Sixth International Conference on AIDS to be held in San Francisco in June and the Congress of the World Federation of Hemophilia, scheduled for Washington in August.

But many AIDS activists complain that the measure does not go far enough. They believe that AIDS should be removed entirely from the list of contagious diseases, as the US Centers for Disease Control recently recommended. AIDS had been placed on the list in 1987 by conservative Senator Jessie Helms (Republican, North Carolina) with the effect that carriers had limited rights of entry into the United States. As of last week, about one-quarter of the 12,000 attendees expected at the San Francisco conference had decided to boycott the meeting because of the visa restrictions. AIDS activists said they did not expect the new measures to change the boycott picture substantially.

G. Christopher Anderson

ongoing studies at IPCC. Although the Bush administration "does not believe that further research is any substitute for action", Bromley said, it is committed to the IPCC aim for an international "Framework Convention" to set global emission levels, rather than starting an international policy-making process of its own.

US officials say that this week's conference will be different from the meetings of IPCC in that it will bring together the scientific and economics aspects of global warming.

Among the attending nations are the Soviet Union, Japan, Brazil, the United Kingdom, Australia, Canada, Poland, and Indonesia. Although Bush had previously promised that China - the largest producer of greenhouse gases - would be invited, diplomatic relations between the two countries have soured considerably since the 1988 presidential campaign.

G. Christopher Anderson 